\title{
Kittlitz's Murrelet Seasonal Distribution and Post-breeding Migration from the Gulf of Alaska to the Arctic Ocean
}

\author{
John F. Piatt, ${ }^{1,2}$ David C. Douglas, ${ }^{3}$ Mayumi L. Arimitsu, ${ }^{3}$ Michelle L. Kissling, ${ }^{4}$ Erica N. Madison, ${ }^{1}$ \\ Sarah K. Schoen, ${ }^{1}$ Kathy J. Kuletz ${ }^{5}$ and Gary S. Drew ${ }^{1}$
}

(Received 24 March 2021; accepted in revised form 18 May 2021)

\begin{abstract}
Kittlitz's Murrelets (Brachyramphus brevirostris) nest during summer in glaciated or recently deglaciated (post-Wisconsin) landscapes. They forage in adjacent marine waters, especially those influenced by glacial meltwater. Little is known of their movements and distribution outside the breeding season. To identify post-breeding migrations of murrelets, we attached satellite transmitters to birds $(\mathrm{n}=47)$ captured at sea in the Gulf of Alaska and Aleutian Islands during May-July 2009-15 and tracked 27 birds that migrated from capture areas. Post-breeding murrelets migrated toward the Bering Sea, with short periods of movement (median $2 \mathrm{~d}$ ) separated by short stopovers (median $1 \mathrm{~d}$ ). Travel speeds averaged $79.4 \mathrm{~km} \mathrm{~d}^{-1}$ (83.5 SD, 449.1 maximum). Five Kittlitz's Murrelets tagged in Prince William Sound in May migrated to the Bering Sea by August and four continued north to the Arctic Ocean, logging 2500-4000 km of travel. Many birds spent 2-3 weeks with little movement along coasts of the Alaska Peninsula or eastern Bering Sea during late August through September, also the pre-basic molt period. Ship-based surveys, many of which were conducted concurrently with our telemetry studies, confirmed that substantial numbers of Kittlitz's Murrelets migrate into the Arctic Ocean during autumn. They also revealed that some birds spend winter and spring in the Bering Sea in association with ice-edge, polynya, or marginal ice zone habitats before returning to summer breeding grounds. We conclude that this species is best characterized as a sub-Arctic and Arctic species, which has implications for future risk assessments and threat mitigation.
\end{abstract}

Key words: Kittlitz's Murrelet; Brachyramphus brevirostri; satellite tracking; Argo; movement ecology; migration; seabird; Gulf of Alaska Bering Sea; Chukchi Sea; Arctic

RÉSUMÉ. Les guillemots de Kittlitz (Brachyramphus brevirostris) nichent pendant l'été dans des lieux englacés ou récemment déglacés (post-Wisconsinien). Ils se nourrissent dans les eaux de mer adjacentes, surtout celles influencées par l'eau de fonte glaciaire. On en sait peu sur leurs mouvements et leur répartition en dehors de la saison de reproduction. Afin de déterminer les migrations des guillemots après la reproduction, nous avons fixé des émetteurs satellitaires à des oiseaux $(\mathrm{n}=47)$ capturés en mer dans le golfe d'Alaska et sur les îles Aléoutiennes, de mai à juillet 2009 à 2015, ce qui nous a permis de suivre 27 oiseaux qui ont migré depuis l'endroit où ils ont été capturés. Après la reproduction, les guillemots ont migré vers la mer de Béring, avec de courtes périodes de mouvement (médiane de $2 \mathrm{~d}$ ) parsemées de brèves escales (médiane de $1 \mathrm{~d}$ ). Leurs vitesses de déplacement ont atteint 79,4 $\mathrm{km} \mathrm{d}^{-1}$ en moyenne (écart type de 83,5 et maximum de 449,1). Cinq guillemots de Kittlitz étiquetés au golfe du Prince William en mai ont migré vers la mer de Béring avant le mois d'août, et quatre ont poursuivi leur route vers le nord, jusqu'à l'océan Arctique, ce qui s'est traduit par des déplacements de 2500 à $4000 \mathrm{~km}$. De nombreux oiseaux ont passé de deux à trois semaines à se déplacer très peu sur les côtes de la péninsule d'Alaska ou de l'est de la mer de Béring de la fin d'août jusqu'en septembre, ce qui correspond également à la période de mue de prébase. Des dénombrements effectués par bateau, dont grand nombre ont été réalisés en même temps que nos études télémétriques, ont permis de confirmer qu'un nombre important de guillemots de Kittlitz migrent dans l'océan Arctique à l'automne. Ils ont également permis de révéler que les oiseaux passent l'hiver et le printemps dans la mer de Béring, plus précisément dans les habitats de lisières de glace, de polynie ou de zones de marge glaciaire avant de regagner leurs lieux de reproduction d'été. Nous concluons que cette espèce est mieux caractérisée comme espèce subarctique ou espèce arctique, ce qui a des incidences sur l'atténuation des menaces et sur les évaluations des risques futures.

Mots clés : guillemot de Kittlitz; Brachyramphus brevirostris; repérage par satellite; Argo; écologie du mouvement; migration; oiseau de mer; golfe d'Alaska; mer de Béring; mer des Tchouktches; Arctique

Traduit pour la revue Arctic par Nicole Giguère.

\footnotetext{
${ }^{1}$ U.S. Geological Survey, Alaska Science Center, 4210 University Dr., Anchorage, Alaska 99508, USA

${ }^{2}$ Corresponding author: jpiatt@usgs.gov

${ }^{3}$ U.S. Geological Survey, Alaska Science Center, 250 Egan Drive, Juneau, Alaska 99801, USA

${ }^{4}$ U.S. Fish and Wildlife Service, 3000 Vintage Boulevard, Suite 201, Juneau, Alaska 99801, USA; current address: University of

Montana, Wildlife Biology Program, 32 Campus Dr. Missoula, Montana 59812, USA

${ }^{5}$ U.S. Fish and Wildlife Service, 1011 E. Tudor Rd., Anchorage, Alaska 99503, USA

(C) The Arctic Institute of North America
} 


\section{INTRODUCTION}

The Kittlitz's Murrelet (Brachyramphus brevirostris) is a small ( $\sim 240 \mathrm{~g})$ member of the Family Alcidae that typically nests on glacially modified landscapes and forages in adjacent glacial-marine seascapes. During summer, this species is most abundant in glacially active areas of the Gulf of Alaska (Arimitsu et al., 2011; Kissling et al., 2011; Kuletz et al., 2011a, b; Piatt et al., 2011). Lesser numbers are scattered in isolated populations among the Aleutian Islands, northwestern Alaska, and the Russian Far East, at sites associated with inland or coastal glacier remnants or post-glacial habitats (Artukhin et al., 2011; Day et al., 2011; Madison et al., 2011; Kissling and Lewis, 2016). Mated pairs nest solitarily, laying a single egg on the ground, usually in secluded mountainous areas (Lawonn et al., 2018) and often near large glacial icefields or tidewater glaciers (Piatt et al., 1999; Kissling et al., 2015a; Felis et al., 2016). At sea, Kittlitz's Murrelets forage in small groups or individually on schooling forage taxa such as capelin (Mallotus catervarius), Pacific sand lance (Ammodytes personatus), Pacific herring (Clupea pallasii), and zooplankton (esp. Thysanoessa euphausiids and amphipods) during summer and autumn. During winter and spring, their diet includes a higher proportion of zooplankton (Hobson et al., 1994; Hatch, 2012; Day et al., 2020). In the Gulf of Alaska, Kittlitz's Murrelets concentrate summer foraging in glacially influenced marine waters, where prey availability can be enhanced near tidewater glaciers and in glacialmarine waters up to $10-40 \mathrm{~km}$ "downstream" from glacial river outflows (Arimitsu et al., 2012, 2018; Renner et al., 2012). The species' rarity and patchy distribution, frequent association with glacier and sea ice-dominated habitats that are receding rapidly (Kuletz et al., 2003; Arimitsu et al., 2016; Stempniewicz et al., 2017; Day et al., 2020), and population declines in core breeding areas have raised conservation concerns (USFWS, 2013).

Adding to those concerns, we know little about the distribution and ecology of Kittlitz's Murrelets during the 8-month period outside the breeding season (Day et al., 2020) and therefore little about the threats these birds might face during most of their annual life cycle. There is evidence that some birds may overwinter near summer breeding grounds in coastal regions of the Gulf of Alaska or offshore near the shelf edge, while some may also migrate north into the Bering or Chukchi Seas (summarized in Day et al., 2020). At present, however, the origins, movements, and non-breeding destinations of murrelets remain largely speculative. Identification of post-breeding migration routes, molting areas, and wintering areas are required to better understand Kittlitz's Murrelet non-breeding season ecology (USFWS, 2013). To address these data gaps, we captured birds during summer and attached solar-powered satellite transmitters in order to track post-breeding season migration of birds during autumn and early winter. This is the first satellite-tracking study of Kittlitz's Murrelet, although a study of the closely related Marbled Murrelet ( $B$. marmoratus) in the north Pacific was recently conducted using the same tracking technology (Bertram et al., 2016; Northrup et al., 2018). In this paper, we document extensive autumn movements and diving behavior of the species, and we compare tracking data with year-round distribution data on Kittlitz's Murrelets recorded during extensive at-sea surveys (North Pacific Pelagic Seabird Database [NPPSD], Drew and Piatt, 2020).

\section{METHODS}

\section{Animal Capture}

Most Kittlitz's Murrelets $(n=44)$ were captured at night from an inflatable boat in open waters using a dip net to scoop up individuals that had been momentarily disoriented by a bright spotlight (Whitworth et al., 1997). On Kodiak Island, we captured three Kittlitz's Murrelets at their nests during incubation using a mist net. In total, 47 Kittlitz's Murrelets were tagged with platform transmitter terminals (PTTs or tags) at six locales during six summers from 2009 to 2015 (Table 1). Average time between capture and release was approximately 1 hour. PTTs were attached dorsally between the wings (Fig. 1) using 3-0 nonabsorbable monofilament sutures guided through four parallel channels along the anterior-posterior axis of the bird (Adams et al., 2012; Loredo et al., 2019). However, those deployed initially in 2009 were secured with two barbed prongs and glue (Lewis and Flint, 2008); a method that was abandoned after it was found to be inferior. For most tags deployed after

TABLE 1. Location, month and year (sample size in parentheses) that Kittlitz's Murrelets were tagged with $5 \mathrm{~g}$ Argos satellite transmitters. Birds that moved more than $75 \mathrm{~km}$ from capture site were presumed migrators (see Methods and Appendix 1 for details).

\begin{tabular}{|c|c|c|c|c|c|}
\hline Alaska site & General location & May & June & July to August & Migrated (n) \\
\hline Glacier Bay & $58.72^{\circ} \mathrm{N}, 136.28^{\circ} \mathrm{W}$ & $2011(2)$ & - & - & 0 \\
\hline \multirow[t]{4}{*}{ Icy Bay } & $59.95^{\circ} \mathrm{N}, 141.43^{\circ} \mathrm{W}$ & $2010(3)$ & - & 2009 (2) & 9 \\
\hline & & $2011(2)$ & - & $2010(3)$ & - \\
\hline & & - & - & $2011(3)$ & - \\
\hline & & - & - & $2012(1)$ & 9 \\
\hline \multirow[t]{2}{*}{ Prince William Sound } & $60.75^{\circ} \mathrm{N}, 147.85^{\circ} \mathrm{W}$ & $2011(6)$ & - & $2010(5)$ & 14 \\
\hline & & - & - & $2013(9)$ & - \\
\hline Kachemak Bay & $59.69^{\circ} \mathrm{N}, 151.16^{\circ} \mathrm{W}$ & - & - & $2009(5)$ & 0 \\
\hline Atka Island & $52.25^{\circ} \mathrm{N}, 174.30^{\circ} \mathrm{W}$ & - & - & $2011(3)$ & 2 \\
\hline Kodiak Island & $57.47^{\circ} \mathrm{N}, 154.71^{\circ} \mathrm{W}$ & - & $2015(3)$ & - & 2 \\
\hline
\end{tabular}




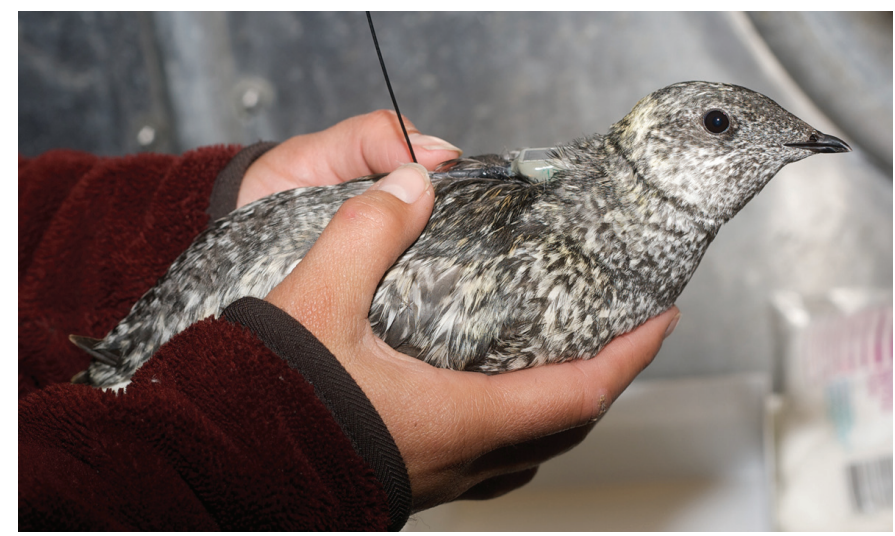

FIG. 1. Kittlitz's Murrelet instrumented with a $5 \mathrm{~g}$ solar-powered satellite transmitter (Photo credit: USGS John F. Piatt).

2009, the antenna of each PTT was bent $\sim 70^{\circ}$ upward near its base to improve skyward propagation of transmissions during typical behaviors.

\section{Satellite-Tracking Equipment}

All murrelets were instrumented with Argos-certified PTTs manufactured by Microwave Telemetry, Columbia, Maryland, USA. We used the $5 \mathrm{~g}(2.0 \%-2.5 \%$ of murrelet body mass) solar-powered PTT-100 model with a 200 $\mathrm{mW}$ transmission output, a 60 or $70 \mathrm{~s}( \pm 5 \mathrm{~s})$ transmission pulse rate, and one of three transmission duty cycles: $10 \mathrm{~h}$ on $-24 \mathrm{~h}$ off $(\mathrm{n}=10), 10 \mathrm{~h}$ on $-48 \mathrm{~h}$ off $(\mathrm{n}=18)$, and $24 \mathrm{~h}$ on $-0 \mathrm{~h}$ off $(\mathrm{n}=19)$. PTTs never transmitted unless solar charging had produced adequate battery voltage. The 24 $\mathrm{h}$ on and $48 \mathrm{~h}$ off intervals were imposed to accumulate solar charging, whereas PTTs with the $24 \mathrm{~h}$ on- $0 \mathrm{~h}$ off duty cycle transmitted anytime sufficient battery voltage was attained. Internal PTT temperature and battery voltage were embedded as sensor data into each message just prior to transmission. Data were received and processed by the Argos System (Fancy et al., 1988) using the least-squares option for estimating location (Lopez et al., 2014).

\section{Satellite Data Preparation and Analysis}

We used a systematic filtering algorithm to exclude implausible Argos locations (Douglas et al., 2012). Filtering criteria considered location quality class, distance moved, movement rate, and turning angle. Argos locations were retained unconditionally if their location class (LC) quality was designated LC 1,2 , or 3 . Lower-quality auxiliary locations (LCs $0, \mathrm{~A}, \mathrm{~B}$, and $\mathrm{Z}$ ) within $10 \mathrm{~km}$ of a preceding or subsequent location were retained by virtue of spatial redundancy, and remaining auxiliary locations were included only if resultant movement rates were less than $100 \mathrm{~km} \mathrm{hr}^{-1}$ and the turning angles ( $\alpha$, in degrees) formed by two sequential vectors of lengths $\mathrm{d} 1$ and $\mathrm{d} 2(\mathrm{~km})$ were not suspiciously acute $(\alpha>-25+\beta \times \ln [$ minimum (d1, d2)], see Douglas et al., 2012). Post-filtering the root-meansquare location errors as estimated by Douglas et al. (2012) were $1.0,2.5$, and $4.3 \mathrm{~km}$ for the unfiltered LC 3, 2, and 1 locations, respectively, and 7.8, 5.7, 11.5, and $7.2 \mathrm{~km}$ for the filtered LC 0, A, B, and Z locations, respectively.

We examined each PTT's time series of temperature and location data for evidence of bird mortality or PTT detachment. Because a resting murrelet's body temperature typically elevated the PTT's internal temperature above that of ambient air and a murrelet's frequent diving behavior regularly introduced short-term variations in temperature that also exceeded ambient conditions, mortality or detachment was evidenced by a persistence of lower-thanexpected temperatures in both magnitude and short-term variability. Furthermore, in many cases, corroborating evidence could be deduced from a concurrent lack of characteristic movements among locations acquired over many days. Otherwise, a murrelet that did not show any evidence of mortality or tag detachment (i.e., a shed or dead classification, hereafter "shed-dead") was assumed to have been alive when the last PTT transmission was acquired.

A murrelet was considered to have migrated if it was located over $75 \mathrm{~km}$ away from its capture locale. We used a $75 \mathrm{~km}$ threshold to overcome occasional shorter forays between adjacent bays and fjords. For each migrant murrelet, we segmented its entire (filtered) location time series into periods of extended movement or periods of localized movement using expectation-maximization binary clustering (Garriga et al., 2016) with a $12 \mathrm{~h}$ smoothing factor in the Program R (R Core Team, 2018) package EMbC (Garriga et al., 2016). Any date (local time) with one or more locations grouped by EMbC as "low velocity" was considered a day of localized movement, that is, a stopover day. Using locations after birds had permanently left their capture locales, we selected the highest quality location for each stopover day based on the Argos LC, sorted them chronologically, then calculated distances and elapsed time between sequential locations. Sequences of stopover days during which the distances between consecutive locations were less than $25 \mathrm{~km}$ were grouped into stopover periods. We used a $25 \mathrm{~km}$ threshold to accommodate spurious movements introduced by location errors. We estimated a generalized location for the stopover period by averaging all stopover-day locations, including linearly interpolated daily locations when the elapsed time was two or more days. Intervening times between stopover periods were considered movement periods.

To identify habitat use within distinct meso-scale areas $\left(10,000-100,000 \mathrm{~km}^{2}\right)$ classified on the basis of major physiographic and oceanographic variation in Alaskan waters, we chronicled the occupancy of marine ecoregions (Piatt and Springer, 2007) for each of the migrant Kittlitz's Murrelets. We also examined diurnal patterns in the murrelet's proximity to the coastline (World Vector Shoreline data set [Wessel and Smith, 1996]). We used a general linear mixed effects model to test for a diurnal distance effect, with individual bird as a random variable to address the repeated samples. We also looked for diel patterns in diving behavior (when birds presumably were 
foraging) as proxied by short-term fluctuations in PTT temperature that likely would accompany diving in the relatively cold ocean. If transmissions collected during a satellite overpass reported a temperature range of $2^{\circ} \mathrm{C}$ or more (akin to Northrup et al., 2018), the time of the overpass was classified as diving behavior. We examined diurnal diving patterns with respect to local solar hour, which was calculated by subtracting 1 hour from the UTC time for every 15 degrees of longitude that the bird was west of the prime meridian. We calculated the proportion of satellite overpasses in 2-hour bins that were classified with diving behavior for all murrelets while resident at their capture locale and again post-departure for the murrelets that migrated. We used 2-hour intervals (instead of 1-hour) to bolster sample sizes at night when transmissions were less frequent because of diminished battery power, and when data collections were less frequent because of fewer satellite overpasses.

\section{Seabird Surveys at Sea}

We used data on the at-sea distribution and abundance of seabirds from the NPPSD to put our satellite-tracking results in context and extend our assessment of seasonal movements and migration of Kittlitz's Murrelets. Data were gathered on nearly half a million transects surveyed by hundreds of observers situated on sea-going vessels in the North Pacific and Arctic Ooceans between 1973 and 2019 (Drew et al., 2015; Drew and Piatt, 2020). The NPPSD includes general seabird surveys that ranged widely over Alaska shelf and deep-ocean waters (e.g., Piatt and Springer, 2003; Hunt et al., 2005; Kuletz et al., 2014; Renner and Kuletz, 2015) and more specific surveys designed to estimate Kittlitz's Murrelet abundance (e.g., Arimitsu et al., 2011, 2012; Kissling et al., 2011; Kuletz et al., 2011b; Madison et al., 2011; Piatt et al., 2011). Of the 460,285 transects we examined in the NPPSD, 1657 transects contained observations of Kittlitz's Murrelet and 10,926 individual murrelets were observed on those transects.

We further queried the NPPSD for records of Kittlitz's Murrelet sightings during four time periods to coincide approximately with their annual cycle of breeding, molt, and migration (Day et al., 2020): 1) non-breeding (November-February; presumed to be the most sedentary period with little molt and no breeding activities), 2) pre-/ early breeding (March-May; birds initiate return to breeding habitat during this time window, pre-alternate partial molt occurs, and nesting may be initiated), 3) peak breeding (June-July; includes average peak of incubation and chick-rearing activity across years and is a time window that reduces the chance of including early or late migrators in our distribution maps), and 4) late/postbreeding (August-October; encompasses dispersal from nesting areas and the pre-basic molt period). We included only Kittlitz's Murrelet observations that were positively identified to species.
We mapped median log densities of murrelets where present within $6495 \mathrm{~km}^{2}$ hexagonal blocks and against the backdrop of terrestrial glacier extent (GLIMS and NSIDC, 2020) and monthly sea ice extent climatology. To map the median seasonal sea ice extent in relation to at-sea survey data, we summarized passive microwave-derived monthly sea ice concentration estimates with $25 \times 25 \mathrm{~km}$ grid cell resolution between 1 November 1978 and 31 December 2019 (Peng et al., 2013, Meier et al., 2017). We took a subset of grid cells with ice concentration values over 0.15 and summarized monthly median sea ice extent using grid cells where frequencies were $50 \%$ or more across all years. We then summarized seasonal median sea ice extent across months in each of the four time periods of the murrelet's annual cycle of breeding and migration (see above).

\section{RESULTS}

The 47 PTT deployments on Kittlitz's Murrelets collectively reported 19,640 locations from live birds; $15,888(80.9 \%)$ of those passed the filtering criteria, of which $7252(45.6 \%)$ were standard LC 1, 2, or 3 locations. Duration of tracking averaged $47.0 \mathrm{~d}( \pm 37.1$, range $5-157$, $\mathrm{n}=47)$. Seventeen PTTs (36\%) ended with shed-dead classifications, two of which were known dead because both PTTs and murrelet prey remains were recovered at nest sites of avian predators, one below a Bald Eagle (Haliaeetus leucocephalus) nest and the other at a Peregrine Falcon (Falco peregrinus) plucking post. Deployments that ended without evidence of mortality or PTT detachment had a significantly longer mean ( $p=0.005$, t-test) tracking duration $(56.4 \pm 42.0 \mathrm{~d}, \mathrm{n}=30)$ than those classified as sheddead (30.5 $\pm 17.2 \mathrm{~d}, \mathrm{n}=17)$. Deployments in 2009 that used the double-prong method to attach PTTs had a significantly shorter mean ( $p=0.01$, t-test) tracking duration (29.6 \pm $11.4 \mathrm{~d}, \mathrm{n}=7$ ) than the suture-only method used in subsequent years $(50.1 \pm 39.2 \mathrm{~d}, \mathrm{n}=40)$. PTTs deployed in May had a significantly longer mean $(p<0.001$, t-test) tracking duration $(86.8 \pm 38.4 \mathrm{~d}, \mathrm{n}=13)$ than those deployed later in the summer $(31.8 \pm 22.7 \mathrm{~d}, \mathrm{n}=34)$.

\section{Migratory Routes}

Twenty-seven (57\%) of the 47 Kittlitz's Murrelet PTTs reported movements that met the post-breeding season migration criteria (Table 1). None of the five murrelets captured at Kachemak Bay during early August 2009 departed the area before the PTTs stopped reporting; three were classified as shed-dead. Also, both birds instrumented at Glacier Bay in early May 2011 did not depart that area after 58 and 74 days of tracking, and they were not classified as shed-dead (Appendix 1). Murrelets that migrated were tracked for a longer (t-test, $p=0.01)$ mean duration (58.1 \pm $41.1 \mathrm{~d}, \mathrm{n}=27$ ) than birds with PTTs that stopped reporting data while still at the deployment locale $(32.1 \pm 24.6 \mathrm{~d}$, $\mathrm{n}=20$ ). Mean mass among 40 murrelets that were measured 


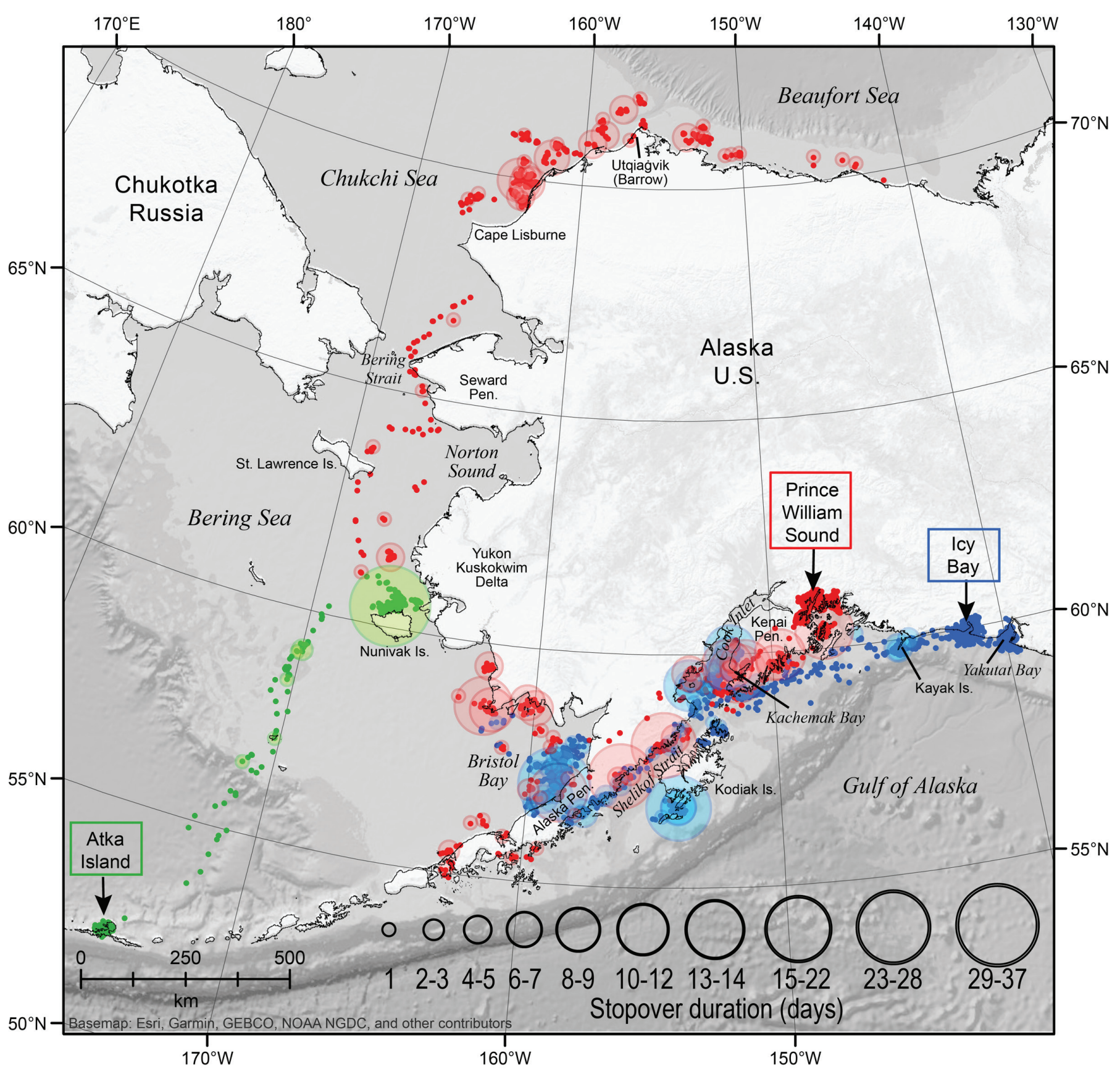

FIG. 2. Summer and autumn migratory locations (small dots) of 25 Kittlitz's Murrelets after they departed three capture locales: Icy Bay (blue, $n=9$ ), Prince William Sound (red, $n=14$ ), and Atka Island (green, $n=2$ ). Stopover areas during migration are shown with shaded circles scaled in size by stopover duration.

was $225.0 \mathrm{~g}( \pm 18.4)$, with no significant difference $(p=0.95$, t-test) between the birds that migrated $(\mathrm{n}=22)$ and those that were not tracked beyond the deployment locale $(\mathrm{n}=18)$. The sample $(\mathrm{n}=16)$ of birds for which sex was determined (11 male, of which seven migrated; five female, of which two migrated) was too small to test for gender bias in capture or migration rates. Males (240.5 g) did not differ ( $p=0.87$, t-test) from females (238.8) in mass.

All Kittlitz's Murrelets that departed from Icy Bay or Prince William Sound $(\mathrm{n}=23)$ migrated westward along the northwestern coast of the Gulf of Alaska (Fig. 2). About half of those $(56 \%)$ reached the Alaska Peninsula before
PTTs stopped reporting, and the remainder (44\%) crossed north into the southeastern Bering Sea near Bristol Bay. Five birds marked in Prince William Sound during May 2011 migrated to Bristol Bay; four continued northward through Bering Strait and into the Chukchi and Beaufort Seas of the Arctic Ocean (Fig. 2, Appendix 1). In midSeptember, two of three murrelets marked at Atka Island in late July 2011 migrated northeast onto the shelf waters of the Bering Sea west of the Yukon-Kuskokwim Delta (Fig. 2). Two of three murrelets marked at Kodiak Island in 2015 and known to be nesting adults, abandoned their nests and promptly moved south in mid-June $\sim 100 \mathrm{~km}$ to 
the southernmost coastal regions of Kodiak Island (not shown in Fig. 2); all three PTTs stopped reporting within $10 \mathrm{~d}$ after deployment. These were the only birds captured at nest sites.

\section{Movement Rates and Distances}

The average daily rate of travel during movement periods was $79.4 \mathrm{~km} \mathrm{~d}^{-1}$ (SD 83.5, interquartile range [IQR] 44.9-102.9, $\max 449.1, \mathrm{n}=125$ movements). A notable capacity for long-distance migration was displayed by two murrelets tagged in May in Prince William Sound; they migrated to the northern Chukchi Sea in just 17-19 days, accumulating a total tracking distance of 2466 and 2893 $\mathrm{km}$, for an average rate of 145 and $152 \mathrm{~km} \mathrm{~d}^{-1}$ (illustrated by the longest, steepest slopes in Fig. 3). Among the 23 migrant murrelets that began in Icy Bay and Prince William Sound, the 10 birds that moved into the Bering Sea were tracked on migration significantly $(p=0.007$, t-test) longer on average ( $47.7 \mathrm{~d})$ than those with tracks that ended in the Gulf of Alaska (16.4 d). Not surprisingly, for all migration movements combined there was a significant positive correlation (Pearson's $r=0.33, p=0.0001$ ) between duration of movement and distance moved.

Birds that were tracked into the Chukchi and Beaufort Seas migrated upwards of $2500-4000 \mathrm{~km}$ from their capture areas in Prince William Sound. Kittlitz's Murrelets instrumented with PTTs ("tagged") during May departed their deployment locales earlier than those tagged in July and August (Fig. 3). The murrelet that traveled farthest was also the earliest to depart on migration (June 23, Fig. 3) and also had the longest tracking duration (157 d, Appendix 1). Daily movement rates were generally faster in the early migration period, whereas extended stopover periods were more common during August and thereafter (as illustrated by flattened line segments in Fig. 3). Transmitters on 12 of the 25 migrants (shown in Fig. 3) stopped providing data while the birds occupied Cook Inlet and coastal areas along the south side of the Alaska Peninsula; most of these stopped transmitting in August.

\section{Stopover and Marine Ecoregions}

After departing the capture locales, most Kittlitz's Murrelets made frequent short stops as they moved westward along the Alaska coast (Fig. 2). Median stopover duration was 1 day, with an IQR of 1-4 d and a 37-day maximum ( $\mathrm{n}=152$ stopovers). Days between stopovers were classified as movement days, and the duration of those movement periods was also relatively short (median 2 days, IQR 1-3, maximum 11, $\mathrm{n}=125$ movements). We required the distance between stopovers to be at least $25 \mathrm{~km}$ and most displacements were notably farther.

Kittlitz's Murrelets collectively occupied 10 distinct marine ecoregions during their summer/autumn migrations through coastal regions of Alaska (Fig. 4). Most individuals occupied several ecoregions during their migration. The

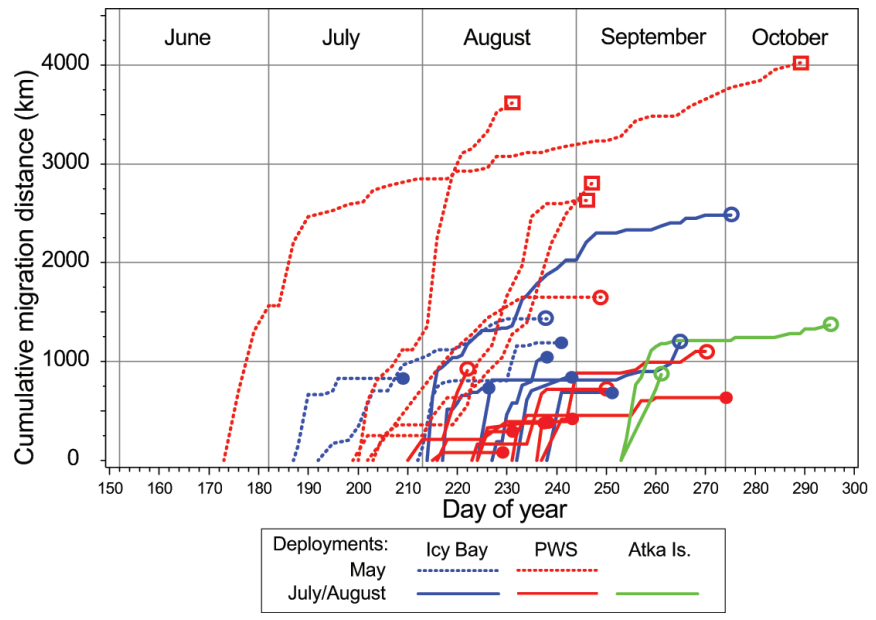

FIG. 3. Cumulative distance moved over time for each of 25 migrant Kittlitz's Murrelets after leaving their capture locale. Lines start on the day of departure. Birds captured in May are shown with broken lines; those captured in July-August, with solid lines. Birds tracked into the Chukchi and Beaufort Seas terminate with open squares, those tracked into the southeast Bering Sea (including Bristol Bay) terminate with open circles, and those tracked into Cook Inlet or along the southern side of the Alaska Peninsula terminate with solid circles. Calculations are based on one location per day (local time) and were disregarded and not added to the cumulative total until they exceeded 25 $\mathrm{km}$. (PWS $=$ Prince William Sound. $)$

western Cook Inlet-Shelikof Strait ecoregion was the most frequently occupied by migrating murrelets (20 of 25 birds). Other frequently occupied ecoregions included the southeastern Cook Inlet-Kodiak Upwelling (14 of 25 birds), the northern Gulf of Alaska Shelf (12 of 25), the eastern Bering Sea-Alaska Coastal (12 of 25), and the Alaska Peninsula Coastal and Shelf (11 of 25). Four of the five murrelets tagged during May in Prince William Sound migrated to the Beaufort-Chukchi Coastal-Shelf ecoregion (Fig. 4), and the two that departed earliest migrated the fastest (Fig. 3).

\section{Diel Diving Patterns}

The proportion of satellite overpasses that recorded large $\left(>2^{\circ} \mathrm{C}\right)$ temperature fluctuations indicative of diving into cold water revealed a distinct diurnal diving pattern (Fig. 5a). When birds were resident at their capture locales, diving activity was detected during all daytime hours but declined markedly at night. During the post-breeding migration period, a similar diurnal diving pattern was observed, but with reduced activity in the early morning and late evening. We also found a diurnal distance-toshore pattern while murrelets were occupying the locales where they were captured (Fig. 5b). Before migrating, standard quality (LC 1, 2, and 3) locations $(\mathrm{n}=5629)$ from all 47 Kittlitz's Murrelets were significantly farther offshore at night (6 PM to $6 \mathrm{AM}$ ) than during the day ( $p<$ 0.001, GLMM). The nighttime least-squares mean distance to the coast was $0.98 \mathrm{~km}(0.07 \mathrm{SE})$, compared with the daytime distance of $0.29 \mathrm{~km}(0.07 \mathrm{SE})$. After migrating, the murrelets were much more variable with respect to their distance offshore (Fig. 2). The median distance offshore 


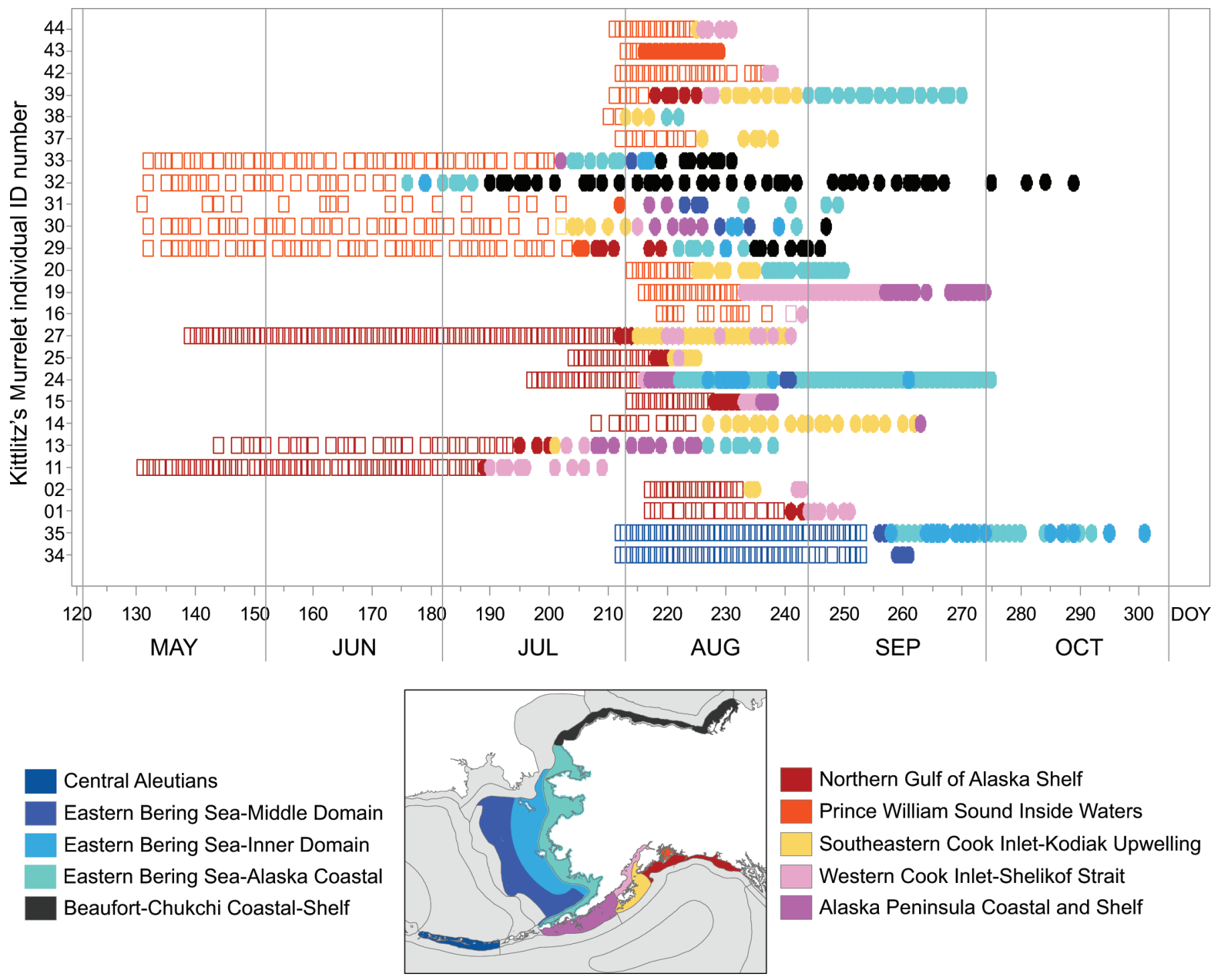

FIG. 4. Daily location time series (top graphic) for 25 Kittlitz's Murrelets color-coded with respect to occupancy of different marine ecoregions (bottom legend). Each horizontal line of symbols represents one murrelet, beginning on the day of year when it was captured and instrumented with a satellite transmitter. Open squares denote pre-migratory locations and solid ovals denote locations after departing the capture locale. Individual ID numbers (y-axis) cross-reference those in Appendix 1. Coastal lagoon and shelf break ecoregions along the northern coast of Alaska were combined with the Beaufort-Chukchi Coastal-Shelf Ecoregion.

during migration was $3.5 \mathrm{~km}(0.7-12.6 \mathrm{IQR}$, maximum 213, $\mathrm{n}=1601)$, still reflecting a predominantly coastal affinity. Among migratory locations that were generally coastal (e.g., 3, 5, or $10 \mathrm{~km}$ from the shoreline), the diurnal pattern described above remained statistically detectable. For example, among 897 standard quality locations that were within $5 \mathrm{~km}$ of the shoreline during migration, the nighttime least-squares mean distance to the coast was $1.64 \mathrm{~km}(0.11$ $\mathrm{SE})$, compared to a daytime distance of $1.26 \mathrm{~km}(0.12 \mathrm{SE})$.

\section{Seasonal Distribution at Sea from Ship-based Surveys}

During the breeding season, at-sea survey data revealed that the highest densities of Kittlitz's Murrelets occurred in the northern Gulf of Alaska, and birds were distributed in general proximity to extant ice sheets and glaciers that border the Gulf of Alaska (Fig. 6). Smaller numbers of murrelets were observed in waters along the Kamchatka Peninsula of Russia and on some Aleutian Islands, as well as in the northern Bering and Chukchi Seas. At-sea survey data collected during the post-breeding period corroborate the satellite-tracking data, showing an apparent postbreeding season redistribution of Kittlitz's Murrelets in the Gulf of Alaska from east to west, a marked reduction in total number of murrelets using the Gulf of Alaska, a modest increase in murrelet numbers occupying shelf waters of the Bering Sea, and a large increase in numbers occupying the Chukchi and Beaufort Seas of the Arctic Ocean. Survey effort and coverage during winter was minimal, so few conclusions can be drawn from the data except to say that modest densities of Kittlitz's Murrelets appeared to overwinter in proximity to summer breeding grounds in the Gulf of Alaska, particularly in Glacier Bay, Prince William Sound, Kenai Peninsula, and Kodiak Island. 
a)

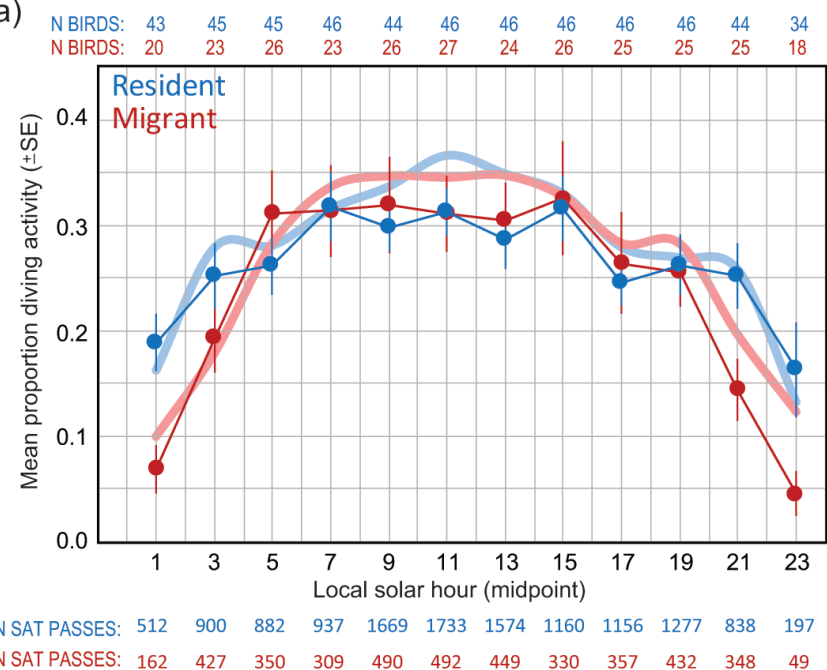

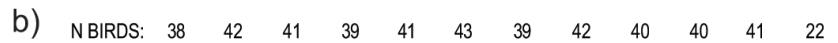

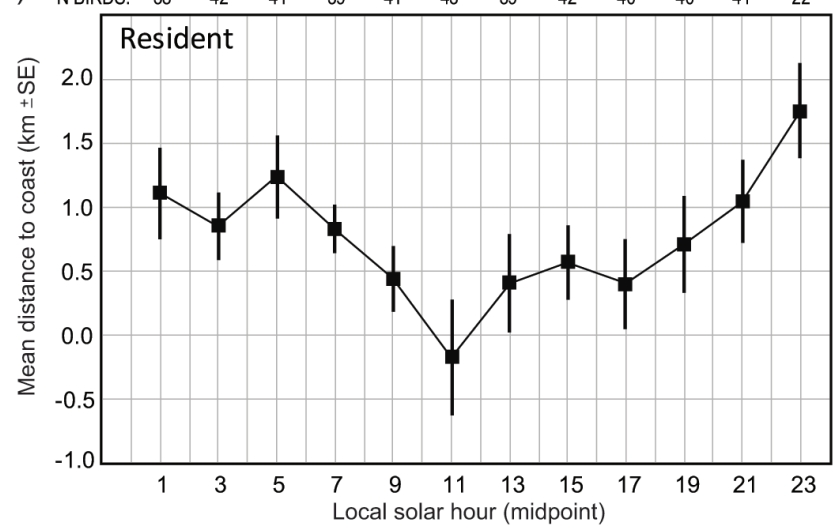

FIG. 5. Diurnal patterns in diving activity and proximity to shore of Kittlitz's Murrelets. (a) Thin lines with dots show the mean $( \pm \mathrm{SE})$ proportion of satellite overpasses that reported a temperature flux of $2{ }^{\circ} \mathrm{C}$ or more (suggestive of diving activity) while resident at capture locales (blue) and while migrating during autumn (red). Sample sizes (n birds) are shown across the top. The thick, smoothed lines were derived from pooled data with sample sizes (n satellite overpasses) shown across the bottom. (b) Mean ( \pm SE) distance to the coastline among all tagged Kittlitz's Murrelets while resident at the locales where they were captured, calculated using only higher-quality Argos location classes (LC 1, 2, 3).

A more extensive historical survey effort during spring revealed that large numbers of Kittlitz's Murrelets occupied the northern Bering Sea at that time, mostly in areas near the southern extent of the sea ice edge or farther north in the marginal ice zone and polynyas near St. Lawrence Island. Moderate murrelet densities were observed in the northern Gulf of Alaska during March-May, probably comprised both overwintering birds and migrant birds beginning to return to summer breeding grounds.

\section{DISCUSSION}

With this first satellite-tracking study of Kittlitz's Murrelet, we documented a remarkable migration away from the species' primary summer breeding habitat in the Gulf of Alaska to previously unknown coastal molting regions, and across 10 marine ecoregions spanning all of Alaska's seas. When the birds left their breeding locales during late summer and autumn, they stopped at presumed feeding and molting grounds along coastal margins of the Gulf of Alaska, the Alaska Peninsula and Bristol Bay, and then many continued north into the Bering Sea and Arctic regions. Most PTTs likely stopped reporting before the birds had completed their migration. Nevertheless, the data obtained followed about half of migrating birds into the southern Bering Sea, and half again of those were tracked much farther north into the Chukchi and Beaufort Seas of the Arctic Ocean. Regardless of origin (capture locale), migrating birds used overlapping migratory routes to similar destinations, revealing that discrete breeding populations comingle to some degree during migration and the non-breeding period, presumably in areas that offer profitable foraging on preferred prey species.

Seasonality of observations of birds at sea during shipbased surveys corroborate the satellite-tracking results and also concur with earlier circumstantial evidence indicating that some birds from the Gulf of Alaska migrate north into the Bering Sea and Arctic Ocean (Day et al., 2011; Kuletz et al., 2015). Once there, they likely remain in the northern portion of their range during winter and early spring to feed along the marginal ice zone and polynyas, similar to some other seabirds (Hunt, 1991; Divoky et al., 2016). Although some Kittlitz's Murrelets occupy ice-free habitats in each phase of their annual cycle, most associate with glacial ice or sea ice to some degree throughout the year, indicating a strong affiliation with ice or associated habitats, such as glacially modified mountains inland or glacial meltwaterinfluenced waters at sea.

\section{Migratory Routes}

Gulf of Alaska: After departing capture locales, the Kittlitz's Murrelet post-breeding season movements to the west and north around coastal Alaska were notable in both distance and speed. When tagged murrelets left Icy Bay and Prince William Sound, they migrated clockwise around coastal Alaska in short alternating bouts of movement and stopover that were typically no more than a few days each. During movement periods, the murrelets averaged $79 \mathrm{~km}$ of travel per day, with peak daily rates approaching $450 \mathrm{~km}$. Similar peak daily travel rates were recorded for Marbled Murrelets that were satellite tracked on an 18-day, $1886 \mathrm{~km}$ migration from British Columbia, Canada, to the Alaska Peninsula in August (Bertram et al., 2016). That a Marbled Murrelet migrated from the southernmost Gulf of Alaska to the same post-breeding areas used by the Kittlitz's Murrelets tagged in this study provides a hint of how much is yet to be learned about the movement ecology of Brachyramphus in the northern Pacific and western Arctic oceans during the non-breeding season.

Northern Bering Sea and Chukchi Sea: The large post-breeding movements northward we documented were consistent with earlier reports of an influx of Kittlitz's 

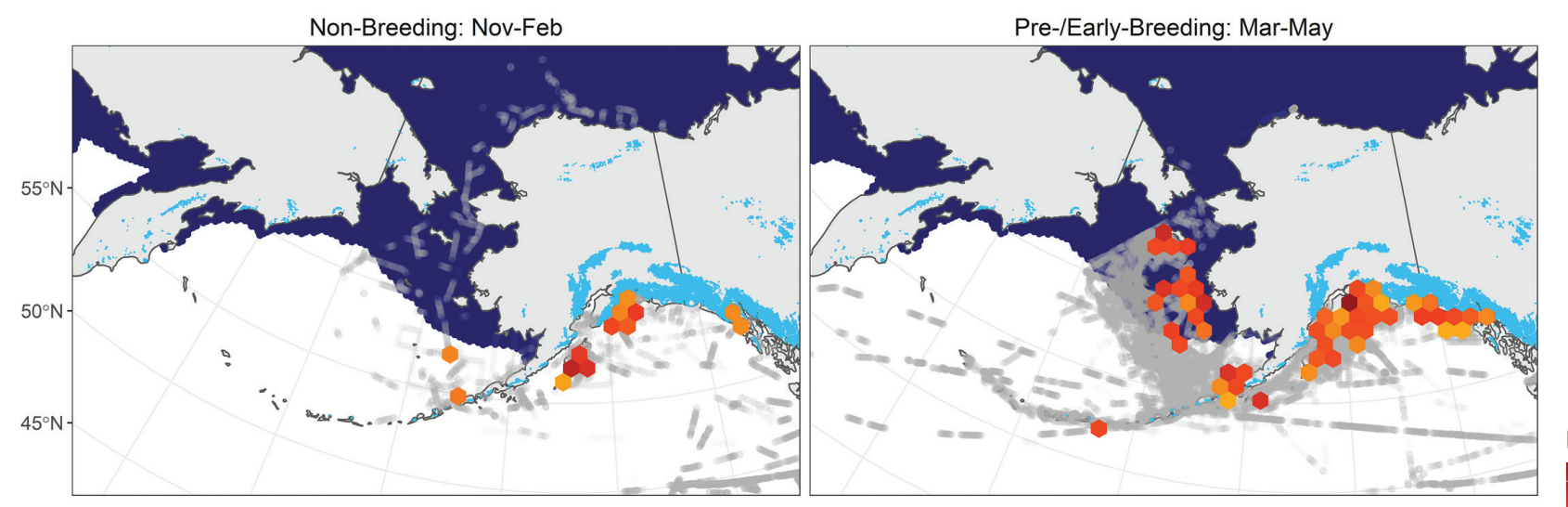

Log Density
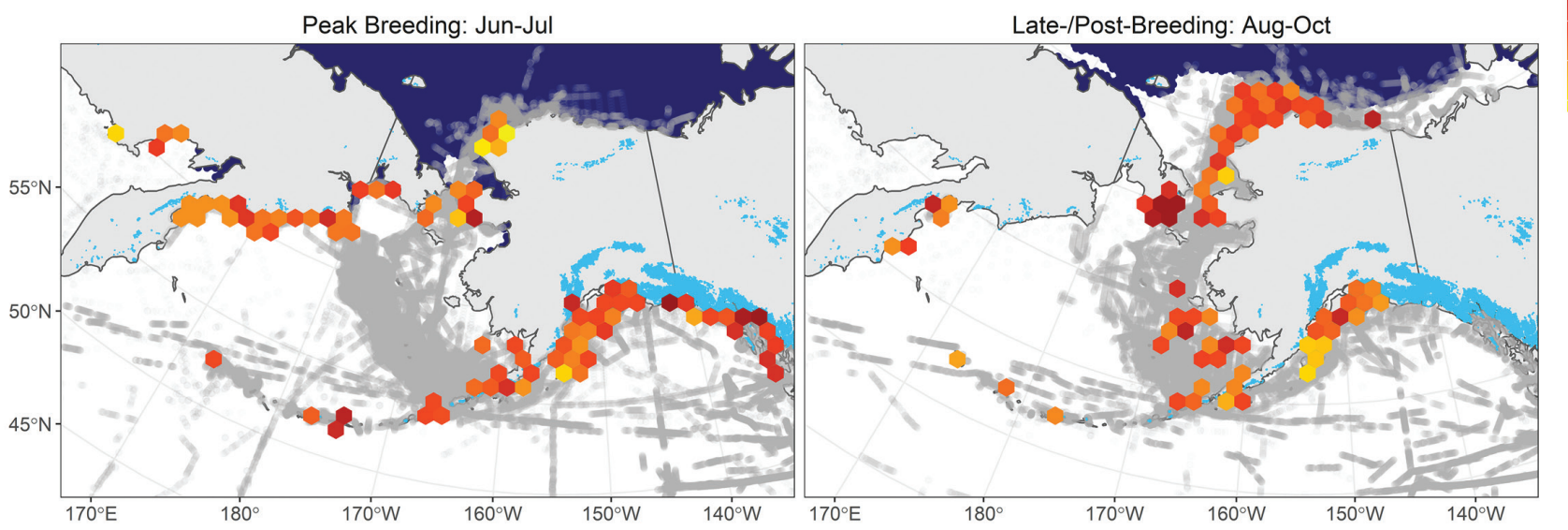

$-1.0$

0.5

0.0

$-0.5$

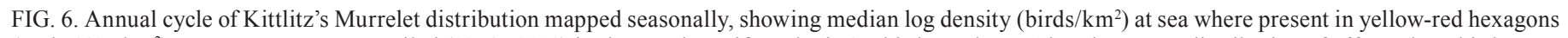

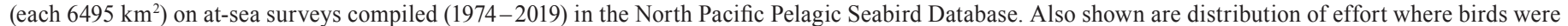

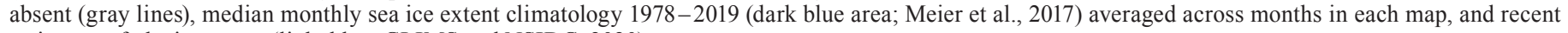
estimates of glacier extent (light blue; GLIMS and NSIDC, 2020).

Murrelets into the southeastern Chukchi Sea during autumn (Day et al., 2011), where extrapolated at-sea population estimates (based on $\sim 75$ records) increased from approximately 450 individuals during April-August to 8500 (95\% CI 2288-17,868) during September-October. Day et al. (2011) speculated that prey abundance, molt destination, or drift by prevailing currents could explain why Kittlitz's Murrelets congregate in northern Alaska (Bering Strait to Beaufort Sea) during autumn. Similarly, in describing seabird "hot spots" in the Chukchi Sea, Kuletz et al. (2015) found significantly higher densities of Kittlitz's Murrelets during autumn (September-November), but not during summer months. Hot spots occurred primarily in the northeastern Chukchi Sea, particularly near Icy Cape and over Barrow Canyon (both also visited by birds tagged in this study). This stretch of coast is also a hot spot for capelin (Logerwell et al., 2015), a prey species targeted by murrelets in Gulf of Alaska fjords. Kittlitz's Murrelets were also common offshore in the Hanna Shoal area, suggesting that the high productivity and biomass of euphausiids in these regions (Dunton et al., 2017), along with longer daylight in autumn, attracted post-breeding migrants (Kuletz et al., 2015). The birds we tracked to this region from the Gulf of Alaska were tagged earlier and commenced migration earlier than most other birds (Fig. 3). Their early departure from Prince William Sound suggests they were either failed or non-breeding individuals, and although they may have molted in northern Alaska, most other tagged Kittlitz's Murrelets appear to have molted elsewhere along the migration route (see below). Birds tagged at Atka similarly migrated northward, along the highly productive innerfront region and stopping near Nunivak Island before the PTTs stopped reporting (Fig. 2).

Migrating to coastal and shelf waters in the northern Bering Sea and the Chukchi Sea during late summer or autumn is not unusual for Kittlitz's Murrelets and other members of Alcidae, including Thick-billed Murres (Uria lomvia), Ancient Murrelets (Synthliboramphus antiquus), and Crested Auklets (Aethia cristatella) (Kuletz et al., 2015; Gaston et al., 2017; Schacter, 2017). However, murrelet abundance (including Ancient and Kittlitz's Murrelets combined) also showed greater interannual variance than spatial variance in the northern Bering and Chukchi Seas (Kuletz et al., 2019), which indicates that migration timing or the numbers actually migrating may be more variable than migration routes among years. It appears that many seabirds move into the region during late summer and autumn to take advantage of high primary and secondary production transported north through Bering Strait by the Anadyr Current (Hunt, 1991; Piatt and Springer, 2007; Kuletz et al., 2015), which enhance local forage fish stocks late in the season (Eisner et al., 2013). Key fish species 
consumed by Kittlitz's Murrelet in the Gulf of Alaska (Hobson et al., 1994; Day et al., 2020) that have been found in abundance in this northern region include capelin and sand lance (Logerwell et al., 2015). Accessibility of prey may also be enhanced in this region during autumn, when diel vertical migrations of zooplankton and fish are maximal, mean biomass in the upper water column is increased, and prey are more dispersed in surface waters (Gonzalez et al., 2021) — conditions similar to those found in glacially modified waters in glacial fjords of the Gulf of Alaska (Arimitsu et al., 2012, 2016).

Beaufort Sea: There are few records of Kittlitz's Murrelet from the Beaufort Sea (Fig. 6, Kuletz et al., 2015), and the distribution and seasonality of the species there remain relatively unknown (Day et al., 2011). However, Kuletz et al. (2015) identified an autumn hot spot for Kittlitz's Murrelets near Point Thomson/Camden Bay in the Beaufort Sea, close to an area visited by two of our tagged Kittlitz's Murrelets (Fig. 2, Appendix 1). Of these two birds, one entered the Beaufort Sea in mid-August and stopped reporting a week later near the Colville River Delta, while the other entered in mid-September and stopped reporting a month later offshore of northeastern Alaska. Ship-based surveys indicate (Fig. 6) that Kittlitz's Murrelets may be more common than suspected in the western Beaufort Sea (Day et al., 2011; Kuletz et al., 2015), especially along the northern Alaska coast and offshore. The westernmost waters of the Beaufort Sea east of Point Barrow can at times form a "krill trap," depending on winds and currents, which attracts foraging whales (Okkonen et al., 2011) and several seabird species, including Kittlitz's Murrelet in autumn (Kuletz et al., 2015).

\section{Molting Locations}

Our best indirect evidence of molt locations came from the 2-3-week stopovers during August-October that are mapped in Fig. 2 and chronicled as flattened line segments in Figure 3. The August-October period corresponds with the peak of pre-basic molt (Pyle, 2009; Day et al., 2020). The pattern of brief movements followed by brief stayovers also indicates that the pre-basic full molt, which includes all primaries (rendering brief flightless periods), may occur in blocks or potentially in sequence (Pyle, 2009; Tonra and Reudink, 2018). Further evidence that these stopovers were associated with molt arises from our observation that PTT data collections often ended during those time periods (Fig. 3 ), regardless of whether birds were tagged in May or two months later in July and August. We speculate that the high number of PTT failures after prolonged stopovers during the expected molt period was caused by molt-induced detachment of the PTT.

\section{Diel Diving Patterns}

Diel patterns in diving behavior, inferred from PTT temperature data, revealed that Kittlitz's Murrelets engaged in relatively high and constant levels of diving activity during the day and notably less at night (Fig. 5a). Similarly, Day and Nigro (2000) found no significant difference in the feeding activity of Kittlitz's Murrelets between morning (0600-1200) and afternoon periods (1200-1930), when observed during mid-summer surveys in Prince William Sound. Although we obtained fewer data at night when both satellite coverage and battery power were diminished, the diurnal diving pattern was strong and robust to different averaging methods, and it was more pronounced during the post-breeding season when day length was shorter (Fig. 5a). The tendency for Kittlitz's Murrelets to dive more during daylight hours, then move away from shore (Fig. 5b) and dive less at night, may be related to changes in availability or visibility of prey between day and night or differences in predation risk and avoidance close to shore between day and night. The predation factor is likely a strong selective force, given that Kittlitz's Murrelet is highly vulnerable to and frequently consumed by common coastal avian predators including Peregrine Falcon, Bald Eagle, and Common Raven (Corvus corax) (see Results, and Kissling et al., 2015b; Day et al., 2020).

\section{Future Research}

Our results provide insights into breeding season behaviors of Kittlitz's Murrelets and avenues for future research. While the PTTs used in this study were designed specifically to minimize the weight of a tag for small diving seabirds by using solar power and sealing them in a waterproof casing, the tags may have still impacted murrelet performance. We cannot dismiss the possibility that capture and tagging may have affected movement (Barron et al., 2010; Hupp et al., 2015) or survival (Peery et al., 2006; Kissling et al., 2015b). However, the murrelets we captured in May $(\mathrm{n}=8)$ remained at capture locales for an average of $62 \mathrm{~d}$ ( $\pm 12 \mathrm{SD}$ ), so tagging obviously did not trigger an immediate departure from breeding grounds or mortality. When these eight birds left their capture locales in June and July, they moved rapidly and over large distances (Fig. 3).

We found no conclusive evidence that any of the eight Kittlitz's Murrelets tagged in May ever attended a nest site, as might be revealed by repeated inland locations accompanied with elevated temperatures (Northrup et al., 2018). We know for sure that the three birds tagged at Kodiak Island in June 2015 were nesting because we captured them at nest sites, and they never returned to their nests after capture, resulting in nesting failure. While we believe that our disturbance at the nest site was the likely cause of failure, it is also possible that poor foraging conditions related to the extreme marine heatwave of 2014-16 contributed to a decision to abandon breeding attempts. Other studies showed that the heat wave led to total breeding failure of Kittlitz's Murrelets on Kodiak Island in 2015 (Knudson et al., 2020) and to extreme mortality and breeding failures of Common Murres (Uria aalge) in the Gulf of Alaska (Piatt et al., 2020). 
Our study underscores the need for developing methods that minimize capture and tagging effects. Future satellitetracking studies that aspire to track Kittlitz's Murrelets during winter and eventually through their full annual cycle will need to 1) improve longevity of the tag's attachment, perhaps by capturing post-molt, and 2) use tags with a battery power source because adequate solar charging during the Arctic winter would likely not be possible. The ability to acquire a finite number of GPS locations from a battery-powered tag weighing under $5 \mathrm{~g}$ has been demonstrated for terrestrial bird species (Scarpignato et al., 2016; $\mathrm{Ng}$ et al., 2018), so development of a similar but marine-worthy design might provide a better winter tracking solution for Kittlitz's Murrelets.

We envision three avenues of future research for Kittlitz's Murrelet. First, we documented extensive mid-summer movements by birds, and this finding has implications for population monitoring programs that estimate abundance and trend of murrelets with "breeding season" surveys. Further study to gain a better understanding of spatial and temporal patterns of migration could improve future (re)design of population-monitoring methods. Second, although Kittlitz's Murrelet is considered a sub-Arctic species, our results demonstrate seasonal migration to and occupation of Arctic waters by a substantial proportion of the population. There, murrelets are subject to increased risks associated with climate change, offshore oil and gas development, and increasing shipping and tourism traffic. To assess those risks, we need better information on the timing and magnitude of post-breeding migrations into the Arctic Ocean. And third, given the projected loss of ice habitats in the coming decades, further research is needed to determine the role of glacial ice and sea ice as drivers of Kittlitz's Murrelet population biology, and the degree to which ice influences this species' contemporary life history (e.g., Laidre et al., 2008).

\section{CONCLUSIONS}

We instrumented 47 Kittlitz's Murrelets with satellite transmitters during the breeding season and obtained migratory movements for 27 of the marked birds after they departed their capture locales. All the post-breeding migratory tracks (collected during June-September) followed the Alaska coast in a clockwise direction from the northern Gulf of Alaska toward Cook Inlet, the Alaska Peninsula, and Bering Sea, with four individuals continuing into the Chukchi Sea and two moving beyond Point Barrow into the Beaufort Sea. These long-distance summer and early autumn movements provide new insights into the species' movement ecology and the importance of considering movement when designing population surveys. No birds were tracked into the winter period; circumstantial evidence suggested many PTTs detached during molt. Satellite tracking of Kittlitz's Murrelets during winter will likely require methods different than those we used, such as attaching (preferably post-molt) battery-powered tags with a pre-programmed wintertime data collection schedule. Finally, the species' apparent affinity to glacial ice and sea ice during breeding and non-breeding seasons warrants research to better understand how reduced ice availability due to climate change will impact Kittlitz's Murrelet populations in the future.

\section{ACKNOWLEDGEMENTS}

This paper is dedicated to the memory of John Leslie Wells (1955-2021), a curious and consummate naturalist who warmed both hands before the fire of life. Field work for this study was approved by the U.S. Geological Survey Alaska Science Center (USGS ASC) Animal Care and Use Committee (2008-2013), U.S. Fish and Wildlife Service Animal Care and Use Committee (2009-15), Wrangell-St. Elias National Park and Preserve, Glacier Bay National Park and Preserve, and Kodiak National Wildlife Refuge. All tracking data are publicly available (Piatt et al., 2021). We appreciate assistance in the field from Josh Adams, Andrew Allyn, Vernon Byrd, Robin Corcoran, Erin Cooper, Jonathan Felis, Scott Gende, Nick Hajdukovich, Nick Hatch, Brielle Heflin, Keith Hobson, Tim Knudson, Liz Labunski, Ellen Lance, Steve Lewis, Tim Marcella, Captain Joe McClung (USFWS), Ella Piatt, Martin Renner, Marc Romano, Anne Schaefer, Captain Greg Snedgen (USGS), Kirsten Valentine, and many volunteers and colleagues. The paper benefitted from thoughtful reviews by Josh Adams and three other anonymous reviewers and guidance from Arctic editor Patricia Wells. Funding was provided by the USGS ASC, USGS Science Support Program, USFWS, and U.S. Forest Service (Chugach National Forest). USFWS at-sea surveys were funded by grants from the North Pacific Research Board (2006-10) and the Bureau of Ocean Energy Management (2010-19; M10PG00050, M17PG00017, M17PG00039). Any use of trade, product or firm names in this publication is for descriptive purposes only and does not imply endorsement by the U.S. Government.

\section{REFERENCES}

Adams, J., MacLeod, C., Suryan, R.M., Hyrenbach, K.D., and Harvey, J.T. 2012. Summer-time use of west coast US National Marine Sanctuaries by migrating sooty shearwaters (Puffinus griseus). Biological Conservation 156:105-116. https://doi.org/10.1016/j.biocon.2011.12.032

Arimitsu, M.L., Piatt, J.F., Romano, M.D., and van Pelt, T.I. 2011. Status and distribution of the Kittlitz's Murrelet Brachyramphus brevirostris in Kenai Fjords, Alaska. Marine Ornithology 39:13-22.

http://www.marineornithology.org/content/get.cgi?rn=909

Arimitsu, M.L., Piatt, J.F., Madison, E.N., Conaway, J.S., and Hillgruber, N. 2012. Oceanographic gradients and seabird prey community dynamics in glacial fjords. Fisheries Oceanography 21(2-3):148-169.

https://doi.org/10.1111/j.1365-2419.2012.00616.x 
Arimitsu, M.L., Piatt, J.F., and Mueter, F. 2016. Influence of glacier runoff on ecosystem structure in Gulf of Alaska fjords. Marine Ecology Progress Series 560:19-40.

https://doi.org/10.3354/meps11888

Arimitsu, M.L., Hobson, K.A., Webber, D.N., Piatt, J.F., Hood, E.W., and Fellman, J.B. 2018. Tracing biogeochemical subsidies from glacier runoff into Alaska's coastal marine food webs. Global Change Biology 24(1):387-398.

https://doi.org/10.1111/gcb.13875

Artukhin, Y.B., Vyatkin, P.S., Andreev, A.V., Konyukhov, N.B., and van Pelt, T.I. 2011. Status of the Kittlitz's Murrelet Brachyramphus brevirostris in Russia. Marine Ornithology 39:23-33. http://www.marineornithology.org/content/get.cgi?rn=910

Barron, D.G., Brawn, J.D., and Weatherhead, P.J. 2010. Metaanalysis of transmitter effects on avian behaviour and ecology. Methods in Ecology and Evolution 1(2):180-187. https://doi.org/10.1111/j.2041-210X.2010.00013.x

Bertram, D.F., MacDonald, C.A., O’Hara, P.D., Cragg, J.L., Janssen, M.H., McAdie, M., and Boyd, W.S. 2016. Marbled Murrelet Brachyramphus marmoratus movements and marine habitat use near proposed tanker routes to Kitimat, BC, Canada. Marine Ornithology 44:3-9.

http://www.marineornithology.org/content/get.cgi?rn=1148

Day, R.H., and Nigro, D.A. 2000. Feeding ecology of Kittlitz's and Marbled Murrelets in Prince William Sound, Alaska. Waterbirds 23(1):1-146.

https://www.jstor.org/stable/4641104

Day, R.H., Gall, A.E., Prichard, A.K., Divoky, G.J., and Rojek, N.A. 2011. The status and distribution of Kittlitz's Murrelet Brachyramphus brevirostris in northern Alaska. Marine Ornithology 39:53-63.

http://www.marineornithology.org/content/get.cgi?rn=913

Day, R.H., Kissling, M.L., Kuletz, K.J., Nigro, D.A., and Pyle, P. 2020. Kittlitz's Murrelet Brachyramphus brevirostris. Birds of the World. Ithaca, New York: Cornell Lab of Ornithology. https://doi.org/10.2173/bow.kitmur.01

Divoky, G.J., Douglas, D.C., and Stenhouse, I.J. 2016. Arctic sea ice a major determinant in Mandt's Black Guillemot movement and distribution during non-breeding season. Biology Letters 12(9): 20160275.

https://doi.org/10.1098/rsbl.2016.0275

Douglas, D.C., Weinzierl, R., Davidson, S.C., Kays, R., Wikelski, M., and Bohrer, G. 2012. Moderating Argos location errors in animal tracking data. Methods in Ecology and Evolution 3(6):999-1007.

https://doi.org/10.1111/j.2041-210X.2012.00245.x

Drew, G.S., and Piatt, J.F. 2020. North Pacific pelagic seabird database (NPPSD). NPPSD Version 3.0. Anchorage, Alaska: U.S. Geological Survey https://doi.org/10.5066/F7WQ01T3

Drew, G.S., Piatt, J.F., and Renner, M. 2015. User's guide to the North Pacific Pelagic Seabird Database 2.0. Open-File Report 2015-1123. Anchorage, Alaska: U.S. Geological Survey. 52 p. https://doi.org/10.3133/ofr20151123
Dunton, K.H., Grebmeier, J.M., and Trefry, J.H. 2017. Hanna Shoal: An integrative study of a High Arctic marine ecosystem in the Chukchi Sea. Deep Sea Research Part II: Topical Studies in Oceanography 144:1-5.

https://doi.org/10.1016/j.dsr2.2017.09.001

Eisner, L., Hillgruber, N., Martinson, E., and Maselko, J. 2013. Pelagic fish and zooplankton species assemblages in relation to water mass characteristics in the northern Bering and southeast Chukchi Seas. Polar Biology 36:87-113.

https://doi.org/10.1007/s00300-012-1241-0

Fancy, S.G., Pank, L.F., Douglas, D.C., Curby, C.H., Garner, G.W., Amstrup, S.C., and Regelin, W.L. 1988. Satellite telemetry: A new tool for wildlife research and management. Resource Publication 172. Washington, D.C.: U.S. Department of the Interior, Fish and Wildlife Service. $61 \mathrm{p}$.

Felis, J.J., Kissling, M.L., Kaler, R.S.A., Kenney, L.A., and Lawonn, M.J. 2016. Identifying Kittlitz's Murrelet nesting habitat in North America at the landscape scale. Journal of Fish and Wildlife Management 7(2):323-333.

https://doi.org/10.3996/112015-JFWM-116

Garriga, J., Palmer, J.R.B., Oltra, A., and Bartumeus, F. 2016. Expectation-maximization binary clustering for behavioural annotation. PLoS ONE 11(3): e0151984. https://doi.org/10.1371/journal.pone.0151984

Gaston, A.J., Hashimoto, Y., and Wilson, L. 2017. Post-breeding movements of Ancient Murrelet Synthliboramphus antiquus family groups, subsequent migration of adults and implications for management. PLoS ONE 12(2): e0171726.

https://doi.org/10.1371/journal.pone.0171726

GLIMS and NSIDC (Global Land Ice Measurements from Space and National Snow \& Ice Data Center). 2020. GLIMS Glacier database, Version 1. Boulder, Colorado: NSIDC. https://doi.org/doi:10.7265/N5V98602

Gonzalez, S., Horne, J.K., and Danielson, S.L. 2021. Multi-scale temporal variability in biological-physical associations in the NE Chukchi Sea. Polar Biology 44:837-855. https://doi.org/10.1007/s00300-021-02844-1

Hatch, N.R. 2012. Foraging ecology and reproductive energetics of the Kittlitz's Murrelet (Brachyramphus brevirostris) in Southeast Alaska. MSc thesis, Oregon State University, Corvallis, Oregon.

https://ir.library.oregonstate.edu/concern/graduate_thesis_or dissertations/6h440w309

Hobson, K.A., Piatt, J.F., and Pitocchelli, J. 1994. Using stable isotopes to determine seabird trophic relationships. Journal of Animal Ecology 63:786-798. https://doi.org/10.2307/5256

Hunt, G.L., Jr. 1991. Marine birds and ice-influenced environments of polar oceans. Journal of Marine Systems 2(1-2):233-240. https://doi.org/10.1016/0924-7963(91)90026-Q

Hunt, G.L., Jr., Drew, G.S., Jahncke, J., and Piatt, J.F. 2005. Prey consumption and energy transfer by marine birds in the Gulf of Alaska. Deep Sea Research Part II: Topical Studies in Oceanography 52(5-6):781-797.

https://doi.org/10.1016/j.dsr2.2004.12.024 
Hupp, J.W., Kharitonov, S., Yamaguchi, N.M., Ozaki, K., Flint, P.L., Pearce, J.M., Tokita, K.-I., Shimada, T., Higuchi, H. 2015. Evidence that dorsally mounted satellite transmitters affect migration chronology of Northern Pintails. Journal of Ornithology 156:977-989.

https://oi.org/10.1007/s10336-015-1218-1

Kissling, M.L., and Lewis, S.B. 2016. Nesting activity of the Kittlitz's Murrelet in the Kakagrak Hills, northwestern Alaska. Arctic 69(3):246-252.

https://doi.org/10.14430/arctic4575

Kissling, M.L., Lukacs, P.M., Lewis, S.B., Gende, S.M., Kuletz, K.J., Hatch, N.R., Schoen, S.K., and Oehlers, S. 2011. Distribution and abundance of the Kittlitz's Murrelet Brachyramphus brevirostris in selected areas of southeastern Alaska. Marine Ornithology 39:3-11, http://www.marineornithology.org/content/get.cgi?rn=908

Kissling, M.L., Gende, S.M., Lewis, S.B., and Lukacs, P.M. 2015a. Reproductive performance of Kittlitz's Murrelet in a glaciated landscape, Icy Bay, Alaska, USA. The Condor 117(2):237-248. https://doi.org/10.1650/CONDOR-14-67.1

Kissling, M.L., Lukacs, P.M., Gende, S.M., and Lewis, S.B. 2015b. Multi-state mark-recapture model to estimate survival of a dispersed-nesting seabird, the Kittlitz's Murrelet. Journal of Wildlife Management 79(1):20-30. https://doi.org/10.1002/jwmg.811

Knudson, T.W., Lovvorn, J.R., Lawonn, M.J., Corcoran, R.M., Roby, D.D., Piatt, J.F., and Pyle, W.H. 2020. Can oceanic effects on growth and time to fledging mediate terrestrial predator limitation of an at-risk seabird? Ecosphere 11(10): e03229. https://doi.org/10.1002/ecs2.3229

Kuletz, K.J., Stephensen, S.W., Irons, D.B., Labunski, E.A., and Brenneman, K.M. 2003. Changes in distribution and abundance of Kittlitz's Murrelets Brachyramphus brevirostris relative to glacial recession in Prince William Sound, Alaska. Marine Ornithology 31(2):133 - 140.

Kuletz, K.J., Nations, C.S., Manly, B., Allyn, A., Irons, D.B., and McKnight, A. 2011a. Distribution, abundance and population trends of the Kittlitz's Murrelet Brachyramphus brevirostris in Prince William Sound, Alaska. Marine Ornithology 39:97-109.

http://www.marineornithology.org/content/get.cgi?rn=917

Kuletz, K.J., Speckman, S.G., Piatt, J.F., and Labunski, E.A. 2011b. Distribution, population status and trends of Kittlitz's Murrelet Brachyramphus brevirostris in lower Cook Inlet and Kachemak Bay, Alaska. Marine Ornithology 39(1):85-95. http://www.marineornithology.org/content/get.cgi?rn=916

Kuletz, K.J., Renner, M., Labunski, E.A., and Hunt, G.L., Jr. 2014. Changes in the distribution and abundance of albatrosses in the eastern Bering Sea: 1975-2010. Deep Sea Research Part II: Topical Studies in Oceanography 109:282-292. https://doi.org/10.1016/j.dsr2.2014.05.006

Kuletz, K.J., Ferguson, M.C., Hurley, B., Gall, A.E., Labunski, E.A., and Morgan, T.C. 2015. Seasonal spatial patterns in seabird and marine mammal distribution in the eastern Chukchi and western Beaufort Seas: Identifying biologically important pelagic areas. Progress in Oceanography 136:175-200.

https://doi.org/10.1016/j.pocean.2015.05.012
Kuletz, K.J., Cushing, D.A., Osnas, E.E., Labunski, E.A., and Gall, A.E. 2019. Representation of the Pacific Arctic seabird community within the Distributed Biological Observatory array, 2007-2015. Deep Sea Research Part II: Topical Studies in Oceanography 162:191-210.

https://doi.org/10.1016/j.dsr2.2019.04.001

Laidre, K.L., Heide-Jørgensen, M.P., Nyeland, J., Mosbech, A., and Boertmann, D. 2008. Latitudinal gradients in sea ice and primary production determine Arctic seabird colony size in Greenland. Proceedings of the Royal Society B: Biological Sciences 275:2695-2702.

https://doi.org/10.1098/rspb.2008.0874

Lawonn, M.J., Roby, D.D., Piatt, J.F., Pyle, W.H., and Corcoran, R.M. 2018. Nest-site selection by Kittlitz's Murrelets Brachyramphus brevirostris on Kodiak Island, Alaska. Marine Ornithology 46:33-42.

http://www.marineornithology.org/PDF/46_1/46_1_33-42.pdf

Lewis, T.L., and Flint, P.L. 2008. Modified method for external attachment of transmitters to birds using two subcutaneous anchors. Journal of Field Ornithology 79(3):336-341.

https://doi.org/10.1111/j.1557-9263.2008.00180.x

Logerwell, E., Busby, M., Carothers, C., Cotton, S., DuffyAnderson, J., Farley, E., Goddard, P., et al. 2015. Fish communities across a spectrum of habitats in the western Beaufort Sea and Chukchi Sea. Progress in Oceanography 136:115-132.

https://doi.org/10.1016/j.pocean.2015.05.013

Lopez, R., Malardé, J-P., Royer, F., and Gaspar, P. 2014. Improving Argos doppler location using multiple-model Kalman filtering. IEEE Transactions on Geoscience and Remote Sensing 52(8):4744-4755.

https://doi.org/10.1109/TGRS.2013.2284293

Loredo, S.A., Orben, R.A., Suryan, R.M., Lyons, D.E., Adams, J., and Stephensen, S.W. 2019. Spatial and temporal diving behavior of non-breeding Common Murres during two summers of contrasting ocean conditions. Journal of Experimental Marine Biology and Ecology 517:13 - 24.

https://doi.org/10.1016/j.jembe.2019.05.009

Madison, E.N., Piatt, J.F., Arimitsu, M.L., Romano, M.D., van Pelt, T.I., Nelson, S.K., Williams, J.C., and Degange, A.R. 2011. Status and distribution of the Kittlitz's Murrelet Brachyramphus brevirostris along the Alaska Peninsula and Kodiak and Aleutian Islands, Alaska. Marine Ornithology 39:111- 122 .

http://www.marineornithology.org/content/get.cgi?rn=918

Meier, W.N., Fetterer, F., Duerr, R., Stroeve, J., Savoie, M., and Mallory, S. 2017. NOAA/NSIDC climate data record of passive microwave sea ice concentration, Version 3. Merged GSFC NASA Team/Bootstrap monthly sea ice concentrations from 1978-2019. Boulder, Colorado: NSIDC.

https://doi.org/10.7265/N59P2ZTG

Ng, J.W., Knight, E.C., Scarpignato, A.L., Harrison, A.-L., Bayne, E.M., and Marra, P.P. 2018. First full annual cycle tracking of a declining aerial insectivorous bird, the Common Nighthawk (Chordeiles minor), identifies migration routes, nonbreeding habitat, and breeding site fidelity. Canadian Journal of Zoology 96(8):869-875.

https://doi.org/10.1139/cjz-2017-0098 
Northrup, J.M., Rivers, J.W., Nelson, S.K., Roby, D.D., and Betts, M.G. 2018. Assessing the utility of satellite transmitters for identifying nest locations and foraging behavior of the threatened Marbled Murrelet Brachyramphus marmoratus. Marine Ornithology 46:47-55. http://www.marineornithology.org/content/get.cgi?rn=1248

Okkonen, S.R., Ashjian, C.J., Campbell, R.G., Clarke, J.T., Moore, S.E., and Taylor, K.D. 2011. Satellite observations of circulation features associated with a bowhead whale feeding 'hotspot' near Barrow, Alaska. Remote Sensing of Environment 115(8):2168-2714. https://doi.org/10.1016/j.rse.2011.04.024

Peery, M.Z., Beissinger, S.R., Burkett, E., and Newman, S.H. 2006. Local survival of Marbled Murrelets in central California: Roles of oceanographic processes, sex, and radiotagging. Journal of Wildlife Management 70(1):78-88. https://doi.org/10.2193/0022-541x(2006)70[78:1sommi]2.0.co;2

Peng, G., Meier, W.N., Scott, D.J., and Savoie, M.H. 2013. A longterm and reproducible passive microwave sea ice concentration data record for climate studies and monitoring. Earth System Science Data 5:311-318. https://doi.org/10.5194/essd-5-311-2013

Piatt, J.F., and Springer, A.M. 2003. Advection, pelagic food webs and the biogeography of seabirds in Beringia. Marine Ornithology 31:141-154. http://www.marineornithology.org/content/get.cgi?rn=574

Piatt, J.F., and Springer, A.M. 2007. Marine ecoregions of Alaska. In: Spies, R.B., ed. Long-term ecological change in the northern Gulf of Alaska. Amsterdam: Elsevier. 522-526.

Piatt, J.F., Naslund, N.L., and van Pelt, T.I. 1999. Discovery of a new Kittlitz's Murrelet nest: Clues to habitat selection and nest-site fidelity. Northwest Naturalist 80(1):8-13.

Piatt, J.F., Arimitsu, M., Drew, G., Madison, E.N., Bodkin J., and Romano, M.D. 2011. Status and trend of the Kittlitz's Murrelet Brachyramphus brevirostris in Glacier Bay, Alaska. Marine Ornithology 39:65-75. http://www.marineornithology.org/content/get.cgi?rn=914

Piatt, J.F., Parrish, J.K., Renner, H.M., Schoen, S.K., Jones, T.T., Arimitsu, M.L., Kuletz, K.J., et al. 2020. Extreme mortality and reproductive failure of Common Murres resulting from the northeast Pacific marine heatwave of 2014-2016. PLoS ONE 15: e0226087.

https://doi.org/10.1371/journal.pone.0226087
Piatt, J.F., Kissling, M.L., Arimitsu, M.L., and Douglas, D.C. 2021. Tracking data for Kittlitz's Murrelets (Brachyramphus brevirostris) (ver 1.0, June 2021). U.S. Geological Survey Data Release. https://doi.org/10.5066/P9MMVP9I

Pyle, P. 2009. Age determination and molt strategies in North American alcids. Marine Ornithology 37:219-226. http://www.marineornithology.org/content/get.cgi?rn=847

$\mathrm{R}$ Core Team. 2018. The $\mathrm{R}$ project for statistical computing. Vienna, Austria: R Foundation for Statistical Computing. https://www.r-project.org

Renner, M., and Kuletz, K.J. 2015. A spatial-seasonal analysis of the oiling risk from shipping traffic to seabirds in the Aleutian Archipelago. Marine Pollution Bulletin 101(1):127-136. https://doi.org/10.1016/j.marpolbul.2015.11.007

Renner, M., Arimitsu, M.L., and Piatt, J.F. 2012. Structure of marine predator and prey communities along environmental gradients in a glaciated fjord. Canadian Journal of Fisheries and Aquatic Sciences 69(12):2029-2045. http://dx.doi.org/10.1139/f2012-117

Scarpignato, A.L., Harrison, A.-L., Newstead, D.J., Niles, L.J., Porter, R.R., van den Tillaart, M., and Marra, P.P. 2016. Fieldtesting a new miniaturized GPS-Argos satellite transmitter (3.5 g) on migratory shorebirds. Wader Study 123:240-246. https://doi.org/10.18194/ws.00046

Schacter, C. 2017. Migration dynamics: Testing ecological theory with tracking data for Aethia auklets in the North Pacific. PhD thesis, Memorial University, St. John's, Newfoundland. https://research.library.mun.ca/12995/1/thesis.pdf

Stempniewicz, L., Goc, M., Kidawa, D., Urbański, J., Hadwiczak, M., and Zwolicki, A. 2017. Marine birds and mammals foraging in the rapidly deglaciating Arctic fjord - numbers, distribution and habitat preferences. Climatic Change 140:533-548. https://doi.org/10.1007/s10584-016-1853-4

Tonra, C.M., and Reudink, M.W. 2018. Expanding the traditional definition of molt-migration. The Auk 135(4):1123-1132, https://doi.org/10.1642/AUK-17-187.1

USFWS (U.S. Fish and Wildlife Service). 2013. 12-month finding on a petition to list Kittlitz's Murrelet as an endangered or threatened species. Federal Register 78:61763-61801.

Wessel, P., and Smith, W.H.F. 1996. A global, self-consistent, hierarchical, high-resolution shoreline database. Journal of Geophysical Research 101(B):8741-8743. https://doi.org/10.1029/96JB00104

Whitworth, D.L., Takekawa, J.Y., Carter, H.R., and McIver, W.R. 1997. A night-lighting technique for at-sea capture of Xantus' Murrelets. Colonial Waterbirds 20(3):525-531. https://doi.org/10.2307/1521603 